\title{
ANALISIS ANTROPOLOGI HUKUM TENTANG PENGARUH NILAI-NILAI BUDAYA TERHADAP BUDAYA HUKUM MASYARAKAT BATAK-TOBA TERKAIT DENGAN BATAS USIA KAWIN MENURUT UNDANG- UNDANG NOMOR 1 TAHUN 1974
}

\author{
Zulfadli Barus \\ dosen Fakultas Hukum UPN "Veteran" Jakarta \\ Email: zfdlibrs@yahoo.com
}

\begin{abstract}
Legal Culture as collective respons to the Mariage Law (the Act No. 1 Year 1974), are different in every Adat Communities in Indonesia, especially in the Age Limit for man (19 years old) and woman (16 years old) who are going to marry. So, this Act could be said as living law, if the value system of Adat Law Communities are relevant to the Age Limit to marry which are stated by the Act No.1 Year of 1974. In a few cases in the Batak Toba Society, the average of age limit to get merry are 27 years old for man and 23 years old for woman. Therefore, the legal culture of Batak Toba Society have been supported the Act No.1 Year 1974. It is also could get less deal number of mother who give birth to, if that it's number has been grown up in Indonesia recently.
\end{abstract}

Keywords : Anthropology of Law, the legal culture of Batak Toba Society, Act No.1 Year of 1974, the average of age limit to get merry

\begin{abstract}
Abstrak
Budaya hukum sebagai respon kolektif masing-masing masyarakat Adat, terkait dengan batas usia kawin dalam Undang-Undang Nomor 1 Tahun 1974 disikapi berbeda berdasarkan nilai-nilai yang hidup di masing-masing masyarakat. Aturan tersebut menjadi hukum yang hidup (living law) bila nilai-nilai masyarakat adat tersebut mendukungnya, demikian pula sebaliknya. Dilingkungan masyarakat adat Batak Toba, fenomena rata-rata usia kawin bagi pria (27 tahun) dan wanita (23 tahun), sehingga tidak bertentangan dengan Undang-Undang Nomor 1 Tahun 1974 dan bila dilihat dari aspek kesehatan, hal ini dapat mengurangi resiko kematian ibu karena melahirkan, yang akhir-akhir ini cenderung meningkat di Indonesia.
\end{abstract}

Kata kunci : Antropologi hukum, Hukum adat Batak-Toba, Undang-undang Perkawinan, batas usia perkawinan

\section{A. Pendahuluan}

Antropologi Hukum sebagai ilmu dipengaruhi oleh Antropologi dan IImu Hukum, sehingga sebagai "anak", ia memiliki "bapak" Antropologi dan "ibu" Ilmu Hukum, maka memahami Antropologi dan IImu Hukum adalah prasayrat untuk dapat mengerti Antropologi Hukum. Antropologi Hukum sebagai IImu mempelajari perilaku manusia dengan segala aspeknya yang terkait dengan norma-norma hukum tertulis dan tidka tertulis secara empiris.

Interaksi empirik dalam masyarakat itu tidak hanya menyangkut masyarakat yang budayanya masih sederhana (primitif), tetapi juga masyarakat yang budayanya modern. Dalam hal ini, budaya yang dimaksud adalah budaya hukum, yaitu segala bentuk perilaku budaya manusia yang mempengaruhi atau yang berkaitan dengan masalah hukum (Hilman Hadikusuma : 2004 : 4).

Antropologi hukum mempelajari hukum dari konteks kultur masyarakat tertentu, baik pada masyarakat modern, maupun masyarakat sederhana. Dengan kata lain, Antropologi Hukum adalah Antropologi yang mempelajari Hukum sebagai salah satu aspek dari kebudayaan (J. B. Daliyo cs : 1992 : 139).

Itulah sebabnya penelitian antropologis terhadap hukum sebagai salah satu aspek budaya dibedakan menjadi dua kelompok tujuan, yaitu: penelitian untuk kepentingan pengembangan Antropologi, dan penelitian untuk pengembangan IImu Hukum. Antropologi Hukum menekankan 
pada penelitian untuk pengembangan Ilmu Hukum (J.B.Daliyo cs : 1992 : 140).

Berdasarkan uraian tersebut di atas, dapat dipahami bila perkembangan Antropologi Hukum di Indonesia berkorelasi positif dengan perkembangan IImu Hukum Adat, sehingga antara keduanya dapat dibedakan, tetapi tidak dapat dipisahkan. oleh karena itulah, tulisan ini, penulis beri judul, "Analisis Antropologi Hukum tentang Pengaruh Nilai-Nilai Budaya terhadap Budaya Hukum Masyarakat Batak Toba Terkait dengan Batas Usia Kawin Menurut Undang-Undang No.1 Tahun 1974", untuk mengetahui apakah UndangUndang ini efektif berlaku atau tidak di lingkungan masyarakat, khususnya Pasal 7 ayat (1) UndangUndang No.1 Tahun 1974 terkait dengan batas usia kawin bagi pria (19 tahun) dan wanita (16 tahun) dilihat dari perspektif Antropologi Hukum.

Efektivitas hukum yang dimaksud di sini adalah, apakah ketentuan batas usia kawin secara normatif tersebut (law in books) sama atau tidak dengan yang dipraktekkan (law in action), khususnya di lingkungan masyarakat adat Batak Toba.

Jadi, masalah yang akan dianalisis penulis adalah tentang efektivitas hukum Pasal 7 ayat (1) Undang-Undang No.1 Tahun 1974, apakah dalam praktiknya terjadi kesenjangan antara law in books dengan law in action.

Berdasarkan survey demografi dan kesehatan Indonesia (SDKI) 2012, pada 6.927 responden wanita berusia 15-19 tahun di sejumlah wilayah di Indonesia, 59\% di antaranya pernah melahirkan pertama kali pada usia di bawah 18 tahun. Artinya, satu dari sepuluh remaja perempuan umur 1519 tahun sudah pernah melahirkan atau sedang hamil. Bahkan, sebanyak $11,1 \%$ telah menikah pertama kali pada usia 10-14 tahun(Media Indonesia : 25 Maret 2014). Fakta-fakta tersebut menunjukkan bahwa ketentuan batas usia kawin seperti yang dimaksud dalam Undang-Undang No.1 Tahun 1974 di atas tidak efektif.

\section{B. Unsur Budaya, Wujud Kebudayaan, dan Budaya Hukum}

E. B. Tylor (Soerjono Soekanto : 1990 : 188) mengemukakan bahwa "Kebudayaan adalah kompleks yang mencakup pengetahuan, kepercayaan, kesenian, moral, hukum adatistiadat dan lain kemampuan-kemampuan serta kebiasaan-kebiasaan yang didapatkan oleh manusia sebagai anggota masyarakat". Berdasarkan definisi tersebut dapat disimpulkan bahwa ruang lingkup kebudayaan itu sangat luas, karena meliputi semua aspek kehidupan manusia sebagai anggota masyarakat.
Koentjaraningrat (Koentjaraningrat : Edisi Baru: 180) mengemukakan bahwa "Kebudayaan adalah keseluruhan sistem gagasan, tindakan dan hasil karya manusia dalam rangka kehidupan masyarakat yang dijadikan milik dari manusia dengan belajar". Jadi, menurut Koentjaraningrat kebudayaan berkaitan erat dengan 3 (tiga) hal yang saling terkait.Pertama, hal-hal yang bersifat abstrak seperti sistem gagasan, pengetahuan, kesenian, nilai dan lain-lain.Kedua, hal-hal bersifat nyata (konkrit), yaitu perilaku yang sudah terpola misalnya kebiasaan dan lain-lain. Ketiga, hal-hal yang berkaitan dengan benda-benda fisik sebagai perwujudan dari gagasan dan karya manusia seperti candi, peralatan rumah tangga, bendabenda seni dan lain-lain sebagainya.

\section{Kluckhohn (Soerjono Soekanto : 1990 : 193) mengemukakan bahwa kebudayaan terdiri atas 7 (tujuh) unsur yaitu:}

1. Peralatan dan perlengkapan hidup manusia,

2. Mata pencaharian hidup dan sistem-sistem ekonomi,

3. Sistem kemasyarakatan (sistem kekerabatan, organisasi politik, sistem hukum, sistem perkawinan),

4. Bahasa (lisan maupun tulisan),

5. Kesenian,

6. Sistem pengetahuan, dan

7. Religi (Sistem kepercayaan).

Pembagian unsur-unsur kebudayaan itu mengandung arti bahwa dalam garis besarnya setiap kebudayaan memiliki sekurang-kurangnya unsur-unsur yang sama. Sekalipun ada perbedaan tetapi dianggap bukan perbedaan yang bersifat prinsip.Masing-masing unsur kebudayaan dibentuk oleh satuan-satuan yang lebih kecil (sub unsur) yang disebut kompleks kebudayaan.Kompleks kebudayaan dibentuk oleh satuan-satuan yang lebih kecil lagi yang disebut tema-tema budaya. Tema-tema budaya dibentuk oleh satuan-satuan yang lebih kecil, demikian seterusnya.

Unsur-unsur kebudayaan menjelma dalam tiap macam wujud kebudayaan yang menurut Koentjaraningrat (Soerjono Soeknato : 1990 : 186-187) terdiri atas:

1. Wujud kebudayaan sebagai suatu kompleks dari ide-ide, gagasan, nilai-nilai, normanorma, peraturan dan sebagainya,

2. Wujud kebudayaan sebagai kompleks aktivitas serta tindakan berpola dari manusia dalam masyarakat,

3. Wujud kebudayaan sebagai benda-benda hasil karya manusia. 
Ketiga wujud kebudayaan haruslah dilihat sebagai suatu yang sistemik karena ide atau gagasan sebagai wujud kebudayaan ideal mempengaruhi perilaku manusia dan perilaku manusia dapat menghasilkan benda-benda fisik sebagai hasil karya manusia. Oleh karena itu, ketiga wujud kebudayaan akan selalu terdapat pada tiap unsur kebudayaan. Misalnya unsur sistem kemasyarakatan sebagai unsur kebudayaan yang meliputi kompleks budaya, seperti sistem kekerabatan, sistem hukum, sistem perkawinan dan lain-lain akan menjelma dalam 3 (tiga) wujud kebudayaan. Pertama, wujud kebudayaan pada tataran nilai akan tercermin dalam nilai-nilai sakral yang melandasi ikatan perkawinan seperti misalnya nilai religius-magis sehingga perkawinan adalah suatu peristiwa penting dalam kehidupan seseorang. Untuk melangsungkan perkawinan ada ritual-ritual sakral yang harus dilaksanakan. Kedua, wujud kebudayaan pada tataran perilaku akan tercermin dari ucapan-ucapan perkawinan sebagai perilaku terpola yang harus dilakukan kedua belah pihak seperti ucapan melamar atau upacara pesta perkawinan. Ketiga, wujud kebudayaan pada tataran fisik akan tercermin dari benda-benda fisik yang dipergunakan dalam ritual perkawinan seperti sirih, uang logam, emas, perak, pakaian, piring, perabot rumah tangga dan lain-lain.

Wujud kebudayaan yang akan dibicarakan adalah wujud kebudayaan yang disebut pertama yaitu "cultural system (sistem budaya)". (Soerjono Soeknato : 1990 : 186-187)Sistem budaya merupakan bagian ideal dari kebudayaan karena berkaitan dengan ide-ide, gagasan-gagasan, nilainilai, norma-norma, peraturan dan sebagainya. Ide-ide, gagasan-gagasan atau nilai-nilai itu mengatur dan memberi arah kepada perilaku, tindakan, perbuatan dan karya manusia. (Soerjono Soeknato : 1990 : 186-187)Nilai-nilai budaya, ide atau gagasan tersebut mengarahkan dan menentukan bagaimana suatu masyarakat mempersepsi, bersikap, dan bertindak terhadap setiap gejala yang terdapat dalam kehidupan manusia.Karenanya, nilai-nilai budaya memberi orientasi terhadap bagaimana seharusnya masyarakat bersikap dan bertindak sebagai respon terhadap suatu gejala sosial.

Hal yang sama juga berlaku bagi masyarakat dalam hal menanggapi gejala hukum. Nilainilai budaya mengarahkan atau menentukan bagaimana masyarakat menyikapi gejala-gejala hukum dalam arti apakah hukum tersebut akan dipatuhi, diabaikan, atau dilanggar.Karenanya, budaya hukum itu dapat dilihat sebagai respon kolektif masyarakat terhadap gejala-gejala hukumberdasarkan nilai-nilai budaya yang hidup ditengah - tengah masyarakat tersebut. oleh sebab itu, Stajipto Rahardjo mengemukakan "Budaya hukum suatu bangsa ditentukan oleh nilai-nilai tertentu yang menjadi acuan dalam mempraktikkan hukumnya" (Stajipto Rahardjo : 2003 : 96).

\section{Sistem Hukum dan Budaya Hukum}

Lawrence M. Friedman mengemukakan bahwa sistem hukum memiliki 3 (tiga) unsur yaitu (a) struktur hukum, (b) substansi hukum dan (c) budaya hukum. (M. Sastraprateja:1993 : 7) Unsur struktur hukum meliputi lembaga pengadilan dan ruang lingkup kompetensinya, lembaga legislatif dan lain-lain yang membentuk dan menegakkan hukum. Unsur substansi hukum adalah aturan atau norma dalam sistem hukum yang memberi tuntutan untuk melakukan perilaku yang seharusnya. Unsur budaya hukum adalah sikap manusia terhadap hukum dan sistem hukum yang berkaitan dengan kepercayaan, nilai, pemikiran serta harapannya (M. Sastraprateja :1993 : 7). Sikap manusia terhadap hukum dan sistem hukum itu akan tercermin dari bagaimana manusia itu bertindak mematuhi hukum, menghindari atau menyalahgunakannya (M. Sastraprateja :1993: 7).

Ketiga unsur sistem hukum tersebut dapat dibedakan tetapi tidak dapat dipisahkan karena saling mempengaruhi antara satu sama lain. Unsur struktur hukum berkaitan erat dengan substansi hukum karena substansi hukum (misalnya Undang-undang), dibentuk oleh badan legislatif (DPR) dan eksekutif (Pemerintah), dan ditegakkan oleh badan pengadilan (yudikatif). Unsur substansi hukum berkaitan erat dengan unsur budaya hukum karena budaya hukum berkaitan erat dengan sikap dan perilaku masyarakat terhadap substansi hukum, yaitu apakah hukum itu dipatuhi, dihindari, atau dilanggar. Budaya hukum yang tercermin dari perilaku masyarakat yang melanggar, mematuhi, dan atau menghindari, menunjukkan bahwa dalam kenyataannya substansi hukum tersebut tidak dengan sendirinya berlaku (dipatuhi) meski ia dibuat oleh badan pembentuk hukum yang berwenang, karena faktanya banyak dilakukan pelanggaran terhadap substansi hukum tersebut. Karenanya, Friedman (M. Sastraprateja :1993 : 7) mengemukakan, "Tanpa budaya hukum sistem hukum itu sendiri tidak akan berdaya -seperti ikan mati yang berenang di keranjang, bukan seperti ikan hidup yang berenang di lautnya." Analogi Friedman ini memperjelas betapa eratnya hubungan antara substansi hukum dengan budaya hukum. 
Dapat disimpulkan bahwa aneka ragam persepsi, sikap, dan perilaku masyarakat terhadap substansi hukum (mematuhi, mengabaikan, dan atau melanggamya) sangat bergantung pada nilainilai budaya yang hidup dan melandasi budaya hukum masyarakat tersebut. M. Sastraprateja (M. Sastraprateja :1993 : 7) mengemukakan bahwa "orang bertindak berdasarkan nilai yang diyakininya. Dan ini selalu diulang dan menjadi kaidah hidupnya.Semakin kuat nilai yang dipilih, semakin kuat pengaruh nilai itu atas kehidupannya." Persepsi, sikap, dan perilaku suatu masyarakat terhadap hukum dan sistem hukum ditentukan oleh nilai-nilai budayanya.Nilainilai budaya yang diyakini menentukan bagaimana perilakunya terhadap hukum. Jadi, karena tiap masyarakat atau tiap bangsa mempunyai nilainilai budaya yang berbeda, maka akan berbeda pula budaya hukum antara suatu masyarakat dengan masyarakat lainnya. Dalam hubungan ini, Lawrence M. Friedman (Lawrence M. Friedman : 1984 : 9) mengemukakan bahwa "Setiap masyarakat, setiap negara, setiap komunitas mempunyai budaya hukum."

Ada 2 (dua) hal yang mungkin terjadi berkaitan dengan hubungan antara nilai- nilai budaya dengan budaya hukum.Pertama, masyarakat akan cenderung mematuhi substansi hukum jika nilainilai substansi hukum itu menunjukkan kesesuaian dengan nilai-nilai budayanya. Kedua, akan terjadi pelanggaran terhadap substansi hukum jika nilainilai budaya masyarakat tersebut bertentangan dengan nilai-nilai substansi hukum meski hal itu ditetapkan oleh negara (badan yang berwenang). Dengan demikian, dapat difahamibila nilai-nilai budaya yang diyakini suatu kelompok, suku atau bangsa sangat besar pengaruhnya terhadap budaya hukum kelompok, suku atau bangsa yang bersangkutan. Dengan perkataan lain, budaya hukum pada dasarnya merupakan gambaran dari persepsi, sikap dan perilaku kelompok, suku atau bangsa terhadap hukum dan sistem hukumnya. Perilaku itu dapat berwujud dalam bentuk mematuhi ,melanggar, dan menghindari aturan hukum.

Lebih lanjut Friedman menjelaskan bahwa unsur pertama sistem hukum, yaitu struktur hukum berkaitan dengan macam-macam kelembagaan hukum dengan segala kewenangannya dalam suatu sistem hukum.Kelembagaan hukum dalam garis besamya dapat dibagi atas (a) lembaga pembentuk hukum dan (b) lembaga penegakan/ penerapan hukum. Lembaga pembentuk hukum adalah badan legislatif dan eksekutif sebagai lembaga pembentuk undang-undang atau pembentuk norma-norma hukum yang bersifat abstrak dan umum. Lembaga penegakan/ penerapan hukum adalah badan judikatif atau lembaga peradilan yang bertugas menerapkan aturan hukum atau undang-undang terhadap suatu peristiwa konkrit.

Unsur kedua sistem hukum adalah substansi hukum.Substansi hukum berkaitan dengan normanorma atau kaidah-kaidah hukum yang dibentuk oleh lembaga pembentuk hukum. Substansi hukum dapat meliputi 3 (tiga) macam jenis kaidah hukum yaitu (a) hukum perundang-undangan, (b) hukum jurisprudensi dan (c) hukum tidak tertulis. Kaidah hukum mana di antara ketiganya yang diutamakan bergantung kepada sistem hukum masing-masing.Di dunia ada 2 (dua) jenis sistem hukum yang terkenal yaitu Common Law System (seperti di Inggris dan Amerika) dan Civil Law System (seperti di Belanda). Di luar kedua sistem hukum tersebut masih terdapat berbagai jenis sistem hukum yang lain seperti sistem hukum Islam (Sunarjati Hartono : 1991 : 31).

Sistem hukum Indonesia mewarisi sistem hukum Belanda sehingga condong pada Civil Law Systems. Dalam sistem hukum Indonesia, undang-undang atau hukum perundang-undangan merupakan norma-norma hukum yang utama. Unsur substansi hukum dapat juga dipandang sebagai suatu sistem tersendiri yaitu sistem kaidah hukum positif sehingga sering disebut sistem tata hukum atau sistem hukum dalam arti sempit.Unsur substansi hukum meliputi bidang-bidang hukum tata negara, administrasi negara, pidana, perdata, hukum dagang, dan lain-lain.

Unsur ketiga sistem hukum adalah budaya hukum. Lawrence M. Friedman (Sunarjati Hartono : 1991 : 9) mengemukakan "Setiap masyarakat, setiap negara, setiap komunitas mempunyai budaya hukum." Maka, tiap negara, tiap masyarakat, dan tiap komunitas, dengan sendirinya akan memiliki budaya hukum yang berbeda.

Masyarakat Jepang memiliki "budaya malu" yaitu suatu jenis budaya hukum yang menganggap bahwa penyelesaian suatu masalah berdasarkan hukum positif belum cukup untuk menghapuskan kesalahan seseorang sebelum meminta maaf secara terang-terangan (Satjipto Rahardjo : 2003 : 113). Artinya, penyelesaian berdasarkan hukum negara harus pula dibarengi dengan penyelesaian berdasarkan hukum moral.Bahkan, hukuman moral dianggap jauh lebih berat dari pada hukuman negara. Menurut Satjipto Rahardjo, (Satjipto Rahardjo : 2003 : 114) hal itu disebabkan masyarakat Jepang sekalipun memakai sistem hukum modern tetapi lebih mengutamakan moralitas (supremacy of moral). Hal ini berbeda 
bila dikaitkan dengan budaya hukum yang ada pada kelompok masyarakat tertentu di Indonesia yang memiliki kecenderungan budaya hukum dengan perilaku yang menghindari hukum sebagai sarana penyelesaian masalah lewat budaya transaksionaldalam arti yang menyimpang, sehingga tidak ada lagi bedanya antara fasilitas penjara dengan hotel berbintang bagi narapidana tertentu yang sedang menjalani hukuman.

Melalui "budaya malu", masyarakat Jepang tidak menganggap hukum positif sebagai sarana "ultimum remedium" dalam penyelesaian masalah dalam arti yang positif. Penyelesaian masalah berdasarkan hukum positif dianggap tidak cukup memadai sehingga perlu penyelesaian secara lain yakni penyelesaian secara moral.

contoh-contoh perilaku di atas bagaimana substansi hukum itu dipersepsi dan disikapi secara berbeda dari sudut pandang nilai-nilai budaya yang berbeda yang hidup dalam masyarakat.contohcontoh tersebut menunjukkan dua macam perilaku yang berbeda dalam penyelesaian masalah menurut aturan hukum negara, disebabkan oleh perbedaan nilai-nilai yang dianut. Friedman (Satjipto Rahardjo : 2003 : 8) mengemukakan bahwa "Budaya hukum adalah sikap manusia terhadap hukum dan sistem hukum yang berkaitan dengan kepercayaan, nilai, pemikiran serta harapannya." Sebagai akibat dari pengaruh nilai-nilai budaya tersebut, Friedman (Satjipto Rahardjo : 2003 : 8) lebih lanjut mengemukakan bahwa budaya hukum itulah yang menentukan bagaimana hukum akan dipatuhi, dihindari atau disalahgunakan.

Sikap dan tanggapan terhadap hukum dalam masyarakat Jepang dan Indonesia tersebut bukan gambaran dari sikap pribadipribadi tetapi kecenderungan sikap anggota masyarakat yang dilakukan berulang-ulang sehingga menggambarkan perilaku bersama. Dengan demikian, budaya hukum suatu kelompok masyarakat terbentuk bukan karena produk perilaku satu atau dua orang tetapi produk perilaku bersama anggota masyarakat. Karenanya, Hilman Hadikusuma (Hilman Hadikusuma: 1986 : 51) mengemukakan bahwa "Budaya hukum adalah tanggapan umum yang sama dari masyarakat tertentu terhadap gejala-gejala hukum." Dengan perkataan lain, budaya hukum bukan reaksi pribadi-pribadi tertentu terhadap substansi hukum tetapi reaksi bersama sekelompok orang, suku, atau bangsa. oleh sebab itu, seperti dikemukakan Satjipto Rahardjo (Satjipto Rahardjo : 2003 : 96) "Budaya hukum suatu bangsa ditentukan oleh nilai-nilai tertentu yang menjadi acuan dalam mempraktekkan hukumnya".

\section{Lingkungan Masyarakat Adat}

Van Vollen Hoven membagi masyarakat Indonesia atas 19 (sembilan belas) lingkungan hukum adat (Koentjaraningrat : 1990: 301). Pembagian ini menunjukkan bahwa bangsa Indonesia merupakan bangsa yang multi etnis dengan nilai-nilai budaya yang berbeda-beda. Tiap kelompok masyarakat dalam lingkaran hukum adat memiliki nilai-nilai budaya yang berbeda sehingga patut diduga bahwa masing-masing kelompok masyarakat akan memiliki persepsi, sikap dan perilaku yang berbeda terhadap substansi hukum dan sistem hukum. Artinya, hal ini dapat melahirkan budaya hukum yang berbedabeda antara masing - masing lingkungan adat tersebut. Salah satu dari lingkungan hukum adat yang menjadi fokus pembahasan dalam tulisan ini adalah lingkungan hukum adat Batak-Toba yang asalnya dari Tapanuli, Sumatera Utara, khususnya tentang budaya hukumnya dikaitkan dengan persepsi, sikap, dan perilaku masyarakatnya tentang Perkawinan Usia Dini menurut UndangUndang Nomor 1 Tahun 1974.

Dalam Pasal 7 ayat (1) UU Nomor 1 Tahun 1974 disebutkan bahwa "Perkawinan hanya diijinkan jika pihak pria sudah mencapai umur 19 (sembilan belas) tahun dan pihak wanita sudah mencapai umur 16 (enam belas) tahun." Realitanya, substansi hukum tentang pembatasan usia kawin tersebut dalam kenyataan disikapi secara berbeda oleh berbagai kelompok masyarakat adat, karena ada yang mendukung dan ada yang melanggarnya. Melanggar dalam arti mereka melangsungkan perkawinan di usia dini (dibawah umur 19 tahun bagi pria dan 16 tahun bagi wanita). Sedangkan perilaku yang mendukung berarti mereka melangsungkan perkawinan diusia yang sama dan atau lebih tinggi dari batas usia tersebut.

Persepsi, sikap dan perilaku masyarakat Batak-Toba menunjukkan bahwa mereka memiliki kecenderungan mematuhi aturan pembatasan usia kawin yang diatur dalam Undang - undang Nomor 1 tahun 1974, karena rata-rata usia kawin calon pengantin Batak-Toba adalah di atas ketentuan Undang-undang. Karena, dalam beberapa kasus di kota besar seperti Jakarta ada calon pengantin pria berusia di atas 27 (dua puluh tujuh) tahun dan calon pengantin wanita di atas usia 25 (dua puluh lima) tahun, karena keduanya telah bekerja dan berpendidikan sarjana Strata 1 (S-1). Persepsi sikap dan perilaku masyarakat Batak-Toba ini adalah refleksi dari nilai budaya mereka yang membentuk budaya hukumnya dan dapat berbeda dengan budaya hukum masyarakat adat lain yang membolehkan kawin bagi pasangan 
dengan usia lebih muda dari yang ditentukan oleh Undang-Undang Nomor 1 Tahun 1974.

\section{E. Nilai-nilai Budaya Masyarakat Batak Toba}

Masyarakat Batak-Toba menganut sistem kemasyarakatan patrilineal murni, karena setiap anak menarik garis keturunan atau "marga" berdasarkan garis keturunan bapak.oleh karena itu, anak laki-laki sebagai penerus garis keturunan ayahnya memiliki kedudukan yang penting. Namun, hal itu tidak berarti bahwa kedudukan anak perempuan menjadi tidak penting.Anggapan demikian tentu saja keliru dan hal itu terjadi karena salah paham terhadap sistem kemasyarakatan Batak Toba yang disebut "Dalihan Na Tolu". Dalihan $\mathrm{Na}$ Tolu adalah sistem filsafat masyarakat Batak Toba yang memandang hubungan sosial yang membentuk masyarakat Batak Toba didasarkan oleh tiga hal yaitu "Hula-hula,Dongan tubu dan Boru. "Dalam konteks filsafat inilah, kedudukan anak perempuan juga memiliki kedudukan penting bagi masyarakat Batak Toba.

Salah satu nilai budaya masyarakat Batak Toba yang berkaitan dengan anak adalah nilai "Hagabeon" (Bungaran A.Simanjuntak: 2003 : 371). Istilah "gabe" dalam bahasa Batak Toba mengandung makna mempunyai anak (terutama anak laki-laki). Seorang suami yang tidak mempunyai keturunan anak laki-laki dianggap bernasib malang karena garis keturunannya akan punah jika yang bersangkutan meninggal dunia ("punu"). Maka, lembaga perkawinan bagi masyarakat Batak-Toba sangat penting sebagai lembaga untuk meneruskan garis keturunan marga. Hal itu tidak menjadi faktor yang mendorong seorang ayah untuk sesegera mungkin menikahkan anak laki-lakinya. Bahkan, yang terjadi adalah sebaliknya.

Masyarakat Batak Toba memiliki motto (semboyan) yang sangat terkenal yang berkenaan dengan anak yaitu "Anakhon hi do hamoraon di ahu" Motto ini mengandung arti bahwa anak (terutama laki-laki) adalah segala-galanya bagi seorang ayah. Maka, seorang ayah akan berusaha berbuat yang terbaik bagi anaknya terutama dalam hal pendidikan. Seorang ayah akan berusaha sedapat mungkin mendorong anaknya (terutama laki-laki) untuk sekolah sampai jenjang tertinggi. la tidak akan diminta kawin sebelum menyelesaikan pendidikannya. Apabila sudah menyelesaikan studi dan sudah bekerja barulah yang bersangkutan didorong kawin.Itulah gambaran ideal yang diharapkan oleh seorang ayah dari anaknya laki-laki. oleh karena itu, kemungkinan untuk kawin pada usia muda tidak terpikirkan oleh seorang anak laki-laki dalam masyarakat Batak-Toba.

Bagaimana pandangan masyarakat BatakToba mengenai sifat dan hakikat serta fungsi lembaga perkawinan? Pada dasarnya, masyarakat Batak-Toba memiliki pandangan yang sama dengan masyarakat yang lain di Indonesia mengenai hal ini. Bagi masyarakat Batak-Toba, perkawinan bukan hanya urusan pribadi pihak yang hendak kawin tetapi urusan keluarga dan kerabat.Peristiwa perkawinan bukan hanya penting bagi masing-masing individu tetapi juga bagi seluruh anggota keluarga. Bahkan, perkawinan merupakan peristiwa penting bagi seluruh anggota kerabat karena dengan perkawinan akan terbentuk hubungan kekerabatan antara dua kerabat marga yang berbeda yaitu kerabat pihak laki-laki dengan kerabat pihak perempuan.

Hubungan antar dua kekerabatan yang terbentuk itu bukan hubungan hukum tetapi hubungan yang berkaitan dengan atau memiliki makna spiritual yang bersifat religio- magis.oleh sebab itulah, perkawinan masyarakat Batak-Toba selalu dilakukan dalam upacara ritual tertentu yang sarat makna religio-magis dan disertai penyerahan benda- benda atau sejumlah tertentu uang sebagai syarat yang harus diserahkan pihak lakilaki kepada pihak perempuan.Pihak laki-laki harus menyerahkan sesuatu benda yang disebut "tuhor atau boli" sebagai pengganti berpindahnya si wanita ke dalam kelompok marga (clan) suaminya. Pemberian ini diserahkan dengan pertimbangan demi keseimbangan alam kosmis di kelompok marga si wanita" (Nalom Siahaan: 1982 : 58)

Pada jaman sekarang "tuhor atau boli” tidak lagi berbentuk benda-benda (bride price) tetapi sejumlah uang.Jumlah uang yang wajib diserahkan pihak laki-laki kepada keluarga si wanita sebagai "tuhor atau boli" bergantung dari berbagai faktor. Faktor yang utama adalah kemampuan keluarga laki-laki. Jika keluarga laki-laki kaya, jumlah uang yang diserahkan kepada keluarga wanita akan cenderung banyak. Selain itu, faktor keadaan si wanita juga mempengaruhi. Jika calon mempelai seorang wanita dan berpendidikan tinggi serta sudah bekerja, pihak wanita akan cenderung meminta "tuhor atau boli" yang tinggi. Di Jakarta, dengan kondisi wanita seperti dikemukakan di atas, "tuhor atau boli" wanita tersebut bisa mencapai Rp. 100 juta. Semakin tinggi "tuhor atau boli" semakin tinggi harkat dan martabat pihak keluarga wanita.

Dari sudut fungsinya, masyarakat Batak-Toba seperti halnya sistem kemasyarakatan yang lain yang terdapat di Indonesia memandang lembaga perkawinan sebagai sarana untuk meneruskan 
garis keturunan. Akan tetapi, ada perbedaan fungsi perkawinan bagi masyarakat Batak-Toba dengan masyarakat lain. Bagi masyarakat Batak-Toba, lembaga perkawinan selain memiliki fungsi sebagaimana dikemukakan juga berfungsi meneruskan silsilah marga atau garis keturunan dalam suatu kesatuan marga.

Dalam masyarakat Batak-Toba tanggung jawab untuk meneruskan silsilah keluarga dalam kesatuan suatu marga terletak di pundak anak lakilaki sesuai dengan sistem kemasyarakatan BatakToba yang patrilineal murni. Silsilah satu keluarga dari silsilah satu marga dengan sendirinya akan punah jika kepala keluarga (bapak atau ayah) meninggal dunia tanpa memiliki anak laki-laki. Wanita tidak memiliki tanggung jawab sosial seperti ini karena wanita yang sudah kawin akan meneruskan garis keturunan pihak suaminya.

Dalam usia berapa seseorang sebaiknya kawin? Tidak ada keseragaman pada seluruh sistem kemasyarakatan yang ada di Indonesia mengenai hal ini.Masing-masing sistem kemasyarakatan memiliki pandangan dan alasan tersendiri.

Bagi masyarakat Batak-Toba kapan seseorang sebaiknya kawin atau berkeluarga tidak semata-mata ditentukan oleh usia. Usia hanya salah satu faktor pertimbangan tetapi bukan faktor yang menentukan pertimbangan. Faktor utama untuk menentukan kapan seseorang kawin dalam masyarakat Batak-Toba adalah faktor kemampuan untuk bertanggung jawab. Kemampuan bertanggung jawab tentu saja tidak dapat diukur dari segi usia melainkan gabungan dari berbagai faktor yaitu usia, mental, kemampuan ekonomis dan lain sebagainya. oleh karena itu, faktor pertimbangan yang menentukan keputusan kapan seorang anak sebaiknya kawin atau berumah tangga tidak pernah menjadi sesuatu hal yang sederhana bagi masyarakat Batak-Toba. Berbagai faktor yang menjadi bahan pertimbangan itu memiliki implikasi langsung terhadap rata-rata usia calon pengantin dalam masyarakat Batak Toba. Hal itu tercermin dari rata-rata usia kawin calon pengantin masyarakat Batak Toba yang berada di atas batas usia kawin minimal yang ditentukan oleh undang-undang. Data mengenai hat itu dapat dilihat di Kantor catatan Sipil DKI Jakarta atau dari hasil observasi dalam pesta-pesta perkawinan adat masyarakat Batak-Toba di Jakarta sebagai kota besar. Dari hasil observasi pada pesta perkawinan adat masyarakat Batak Toba dapat diketahui bahwa rata-rata usia pasangan calon pengantin adalah di atas ketentuan usia yang ditetapkan dalam undang-undang. Usia rata-rata calon pengantin pria adalah di atas 27 (dua puluh tujuh) tahun sedangkan usia calon pengantin wanita adalah di atas 23 (dua puluh tiga) tahun. Pada usia tersebut rata-rata kedua calon pengantin (laki-laki dan wanita) telah menyelesaikan jenjang pendidikan minimal strata satu (S-1).

Dalam masyarakat Batak-Toba tidak ada nilai-nilai sosial-budaya yang menganggap bahwa perkawinan pada usia muda sebagai suatu hal yang baik. Sebaliknya, masyarakat Batak-Toba menganggap bahwa perkawinan pada usia muda adalah sesuatu hal yang tidak baik. Apalagi kalau dilakukan oleh seorang anak laki- laki.Kedudukan anak laki-laki adalah sangat penting dalam masyarakat Batak-Toba.Sebab, anak laki-laki adalah penerus garis keturunan orang tuanya dalam silsilah marga sesuai dengan sistem kekerabatan patrilineal murni yang dianut oleh masyarakat Batak-Toba.

Seorang ayah dalam masyarakat BatakToba akan berusaha dengan segala daya upaya mendorong anak laki-lakinya untuk berpikiran maju dan mencapai prestasi setinggi mungkin. Sebab, seorang ayah akan sangat bangga apabila anaknya yang laki-laki telah mencapai kedudukan yang terhormat dalam masyarakat atau memiliki status sosial yang terpandang dan baru kemudian membentuk suatu keluarga. Apalagi jika anak tersebut juga berhasil mencapai pendidikan yang tinggi.Hal ini berkaitan dengan nilai-nilai sosialbudaya masyarakat Batak-Toba mengenai suatu perkawinan yang ideal.

\section{F. Budaya Hukum Masyarakat Batak-Toba tentang Batas Usia Kawin Menurut Undang - Undang Nomor 1 Tahun 1974}

Bagi masyarakat Batak-Toba, suatu perkawinan adalah ideal jika seorang lakilaki sudah mampu mandiri untuk membentuk rumah tangga dari sudut ekonomi, sosial dan budaya,yaitu seorang anak laki- laki idealnya harus sudah bekerja dan mempunyai penghasilan sendiri barulah pantas untuk membentuk rumah tangga.

Pandangan perkawinan ideal sebagaimana dikemukakan di atas bukan hanya menjadi idaman pihak keluarga laki-laki saja.Akan tetapi, juga menjadi idaman pihak keluarga wanita calon istrinya. Keluarga pihak perempuan akan merasa bangga jika calon suami anaknya sudah bekerja dan apalagi kalau memiliki pendidikan yang tinggi. Sebaliknya, pihak keluarga wanita akan merasa enggan untuk mengijinkan anaknya untuk menikah dengan seorang laki-laki yang belum memiliki penghasilan sendiri. Bahkan, pihak 
keluarga wanita akan merasa terhina dan akan mendapat cemoohan dari kerabat-kerabatnya jika mengawinkan putrinya dengan laki-laki yang belum bekerja. Dengan perkataan lain, "gengsi" keluarga pihak perempuan memiliki peranan penting dan menjadi salah satu pertimbangan jika hendak menikahkan putrinya.

Bungaran Simanjuntak (Bungaran A. Simanjuntak: 2003 : 371) mengemukakan bahwa masyarakat Batak Toba memiliki nilai budaya yang tersimpul dalam suatu motto yaitu "hamoraoan (kekayaan), hagabeon (memiliki keturunan atau anak) dan hasangapon (kekuasaan)." Ketiganya satu sama lain berkaitan erat.Ketiga prinsip ini selalu mewarnai pandangan masyarakat BatakToba dalam menanggapi setiap fenomena.Di antara ketiga prinsip tersebut, prinsip "hagabeon" atau memperoleh anak terutama anak laki-laki" merupakan prinsip yang sangat penting. Hal itu berkaitan dengan sistem kemasyarakatan BatakToba yang menganut sistem patrilineal murni.

Dalam sistem kekerabatan seperti ini anak lakilaki memegang peranan dan memiliki kedudukan yang penting karena merupakan penerus garis keturunan ayahnya atau marganya.Dalam rangka menjunjung tinggi prinsip "hagabeon" inilah prinsip kedua yaitu "hamoraoan" atau kekayaan berfungsi. Dalam arti bahwa seorang bapak yang memiliki harta kekayaan akan mempergunakan seluruh hartanya demi kepentingan dan kemajuan anak-anaknya terutama anak laki-laki. Karenanya bagi seorang ayah yang memiliki harta kekayaan akan menjadi celaan kerabat dan masyarakat jika anak- anaknya terutama anak laki-laki gagal dalam pendidikan atau dalam suatu bidang tertentu. Harta kekayaan seorang bapak atau ayah harus dipergunakan untuk mendukung anaknya supaya mencapai prestasi, pendidikan atau kedudukan yang setinggi-tingginya. Dengan jalan demikian, anak yang bersangkutan diharapkan menjadi orang yang memiliki kedudukan atau kekuasaan (Bungaran A. Simanjuntak: 2003 : 371).

Penggunaan harta kekayaan (hamoraoan) seorang ayah untuk kepentingan anak-anaknya berkaitan dengan prinsip ketiga masyarakat Batak-Toba yaitu "hasangapon" atau kekuasaan. Masyarakat Batak-Toba dapat dikatakan sebagai masyarakat yang sangat mendambakan kekuasaan.Kekuasaan sangat penting dan selalu menjadi idaman masyarakat Batak-Toba karena kekuasaan dapat meningkatkan harkat dan martabat atau "gengsi" keluarga.oleh karena itu, untuk mencapai kekuasaan, harta kekayaan kalau perlu harus dipertaruhkan.

\section{G. Budaya Hukum Masyarakat Batak Toba dikaitkan dengan Nikah dini dan Angka Kematian Ibu karena Melahirkan.}

Lembaga Demografi Fakultas Ekonomi Universitas Indonesia (LDFEUI) menengarai penyebab utama peningkatan angka rata-rata kematian ibu (AKI) akibat melahirkan ialah pernikahan usia dini yang gagal dikendalikan pemerintah.

Kepala LDFEUI, Sonny Harry B Harmadi, mengatakan bahwa saat ini di Indonesia ada sekitar $45 \%$ pernikahan perempuan dilakukan pada usia sangat dini atau di bawah 18 tahun. Padahal melahirkan di usia belum sampai 20 tahun berisiko kematian lima kali lipat jika dibandingkan dengan kehamilan saat usia mencapai 20 tahun ke atas, sehingga upaya Indonesia mencapai target penurunan AKI berdasarkan Millennium Development Goals (MDGs), yakni 102 per 100 ribu pada 2015, semakin mustahil.Sony juga mengatakan bahwa rata-rata $\mathrm{AKI}$ saat ini di Indonesia bukanlah 349 per 100 ribu kelahiran hidup, melainkan telah mencapai 359 per 100 ribu kelahiran hidup. oleh karena itu, menurut Sonny, guna menekan pertambahan AKI yang diduga akibat melonjaknya pernikahan dini, pemerintah seyogianya segera merevisi UU No 1/1974 tentang Perkawinan, karena menurutnya batasan minimal perempuan bisa menikah pada usia 16 tahun sudah tidak lagi relevan pada saat ini (Media Indonesia : 2013 : 14).

Sebelumnya, Kepala Badan Kependudukan dan Keluarga Berencana Nasional (BKKBN) Fasli Jalal mengatakan Survei Demografi dan Kesehatan Indonesia (SDKI) 2012 mencatat ratarata AKI pada 2012 mencapai 349 per 100 ribu kelahiran hidup atau meningkat tajam ketimbang hasil survei SDKI pada 2007 yang mencapai 228 per 100 ribu.

Selanjutnya, Deputi Bidang Keluarga Sejahtera dan Pemberdayaan Keluarga BKKBN Sudibyo Alimoeso memaparkan fenomena melahirkan di usia remaja 15-19 tahun pada 2012 melonjak dari 48 per 1.000 perempuan dari tahun sebelumnya 35 per 1.000(Media Indonesia : 2013 :14).

Menurut Ketua Yayasan Kesehatan Perempuan (YKP) Sumrotin K. Susido, Indonesia termasuk negara dengan jumlah pernikahan usia muda tertinggi kedua di ASEAN setelah Kamboja. Ada 22.000 (0,2\%) perempuan Indonesia sudah menikah di usia 10-14 tahun, dan yang menikah pada usia 15-19 tahun ada 11,7\% (Media Indonesia : 06 Maret 2014). Menurut Muhammad Kartono, Mantan Ketua IDI, dipandang dari sudut 
kesehatan, di usia 18 tahun, fungsi reproduksi baru dimulai. Pada perempuan, rahimnya sudah mulai siap tapi belum sempurna.Karenanya, jika remaja hamil ada "persaingan" antara ibu dan anak. Kalau janinnya menang, ibunya akan kekurangan gizi, kekurangan darah, dan anemia. Jika ibunya menang, bayi biasanya akan terlahir dengan kondisi berat badan kurang(Media Indonesia : 06 Maret 2014).

Berdasarkan uraian tersebut diatas dapat dipahami betapa besarnya pengaruh nilai - nilai budaya sehingga ketentuan pembatasan usia kawin minimal dalam UU Nomor 1 Tahun 1974 dapat berlaku efektif dalam masyarakat BatakToba. Pembatasan usia kawin dalam UU Nomor 1 Tahun 1974 dianggap sesuai dengan nilai-nilai budaya yang dianut oleh masyarakat Batak-Toba. Bahkan, dapat dikemukakan bahwa efektivitas pembatasan usia kawin minimal dalam UU Nomor 1 Tahun 1974 didukung oleh masyarakat Batak-Toba bukan karena faktor substansi hukum itu ditetapkan oleh negara tetapi karena sesuai dengan nilai-nilai budaya mereka.Bahkan, dapat dikemukakan bahwa budaya hukum masyarakat Batak-Toba akan tetap menunjukkan kecenderungan tidak menyukai perkawinan pada usia muda terlepas dari ada tidaknya ketentuan pembatasan usia kawin seperti yang diatur dalam Undang - undang Nomor 1 Tahun 1974.

Uraian yang dikemukakan di atas menunjukkan bahwa masyarakat Batak-Toba memiliki kecenderungan sikap dan perilaku (budaya hukum) untuk mematuhi ketentuan pembatasan usia kawin minimal seperti diatur dalam undang-undang. Mengapa?Menurut penulis, faktor penyebabnya bukan karena mereka memiliki kesadaran hukum yang sudah tinggi melainkan karena pengaruh faktor nilai- nilai budayanya.

\section{H. Simpulan}

Berdasarkan uraian yang telah dikemukakan di atas dapat ditarik kesimpulan- kesimpulan sebagai berikut:

1. Anthropologi hukum sebagai cabang anthropologi budaya melihat hukum sebagai gejala budaya sehingga respon kolektif suatu masyarakat terhadap hukum dalam bentuk budaya (mematuhi atau melanggar hukum) sangat dipengaruhi oleh nilai - nilai budaya dari masyarakat itu sendiri. Hukum akan dipatuhi bila tidak bertentangan dengan nilai nilai budaya masyarakat tersebut dan hukum akan dilanggar bila bertentangan dengan nilai - nilai budaya dari masyarakat tersebut.
2. Masyarakat Batak Toba memiliki nilainilai budaya yang menganggap bahwa perkawinan adalah suatu peristiwa penting dalam kehidupan manusia sehingga seseorang tidak baik jika dalam usia muda sudah melangsungkan perkawinan, karena dianggap belum siap secara ekonomi, mental dan sosial. Mereka tidak menyukai perkawinan pada usia muda, karena potensial mendatangkan masalah bagi yang bersangkutan, keluarga kedua belah pihak dan kaum kerabat keduanya. Khusus bagi wanita, pernikahan dini dapat berisiko meningkatkan Angka Kematian Ibu (AKI) akibat melahirkan.

3. Nilai-nilai budaya (hamoraoan, hagabeon dan hasangapon) sangat berpengaruh terhadap perilkau masyarakat Batak Toba terkait dengan aturan pembatasan usia kawin dalam Undang - undang Nomor 1 Tahun 1974,yang cenderung menunjukkan budaya hukum yang mematuhi aturan pembatasan usia kawin minimal tersebut, karena rata-rata usia calon pengantin dalam masyarakat Batak Toba adalah di atas 20 tahun untuk wanita dan 25 tahun untuk laki-laki.

\section{Saran}

1. Untuk merubah budaya hukum yang melanggar aturan batas minimal usia kawin menurut Undang - undang Nomor 1 Tahun 14974 menjadi budaya hukum yang mendukung, perlu dilakukan penyuluhan hukum tentang kesehatan perkawinan khususnya dikalangan generasi muda.

2. Generasi muda masyarakat Batak-Toba yang lahir dan besar di perantauan perlu tetap mempertahankan nila-nilai budayanya agar dapat menghindari perkawinan diusia dini karena dapat mempengaruhi kualitas perkawinan itu.

3. Perlunya Pemerintah merevisi UU Nomor 1 Tahun 1974 tentang Perkawinan khususnya pasal yang mengatur tentang batas usia kawin bagi wanita dari 16 tahun menjadi 18 tahun agar memperkecil risiko kematian bagi lbu yang melahirkan dan juga agar tidak bertentangandengan batas usia dewasa menurut Undang-undang Nomor 12 Tahun 2006 tentang Kewarganegaraan jo Undangundang Nomor 23 Tahun 2002 tentang Perlindungan anak. 


\section{daftar Pustaka}

Bungaran A. Simanjuntak. 'Status dan Kekuasaan Orang Batak Toba' dalam E. K. M. Masinambouw (editor), Hukum dan Kemajemukan Budaya. Jakarta : Yayasan obor Indonesia.

Friedman, Lawrence M. 1984. American Law, WW Norton company. London : The New York.

Hilman Hadikusuma. 1986. Anthropologi Hukum Indonesia. Bandung : Alumni. 2004. Pengantar Antropologi Hukum, Bandung : citra Aditya Bakti.

J.B. Daliyo cs. 1992. Pengantar IImu Hukum Buku Panduan Mahasiswa. Jakarta : Gramedia.

Koentjaraningrat. 1990. Pengantar Ilmu Anthropologi, Edisi baru. Jakarta : Rineka cipta.

Media Indonesia. 2013. Nikah Dini Tingkatkan Kematian Ibu. 22 Agustus 2013.

2014. Kehamilan Dini Sulit Dicegah. Selasa, 25 Maret 2014

2014. Batas Usia Menikah Diusulkan Minimal 18 Tahun. Kamis, 06 Maret 2014

M. Sastraprateja. 1993. Pendidikan Nilai, dalam K. Kaswardi (penyunting), Pendidikan Nilai Memasuki Tahun 2000. Jakarta : Grasindo.

Nalom Siahaan. 1982. Adat Dalihan Natolu, Prinsip dan Pelaksanaannya. Jakarta : Grafika.

Soerjono Soekanto. 1990. Sosiologi Suatu Pengantar. Jakarta : Rajawali Pers.

Stajipto Rahardjo. 2003. Sisi-Sisi Lain Dari Hukum di Indonesia, (Editor: Karolus Kopong Medan dan Frans J. Rengke). Jakarta : Kompas.

Sunarjati Hartono. 1991. Kapita Selekta Perbandingan Hukum. Bandung : citra Aditya Bhakti. 